\title{
Multicentric Castleman's disease in HIV/AIDS patients at an urban HIV clinic in Atlanta, Georgia, in the combined antiretroviral therapy era
}

\author{
Rathi N Pillai ${ }^{1 *}$, Clifford Gunthel ${ }^{2}$, Marylyn Adamski ${ }^{3}$, Marina Mosunjac ${ }^{4}$, Minh Ly Nguyen ${ }^{2}$ \\ From 13th International Conference on Malignancies in AIDS and Other Acquired Immunodeficiencies \\ (ICMAOI) \\ Bethesda, MD, USA. 7-8 November 2011
}

\section{Background}

Multicentric Castleman's disease (MCD), which has been associated with human herpesvirus- 8 (HHV-8), is a lymphoproliferative disorder with an increased prevalence in HIV positive patients [1]. We describe our experience with MCD in a group of patients with HIV/AIDS in an urban HIV clinic.

\section{Methods}

Our clinic serves annually 5,000 patients diagnosed with AIDS. Patients with a diagnosis of multicentric Castleman's disease between 2006 and 2010 were identified from the pathology database at Grady Memorial Hospital or referrals to the clinic. Clinic charts and medical records were abstracted. Patients' demographics, CD4 counts, HIV viral load, HIV and MCD treatment and outcomes were recorded.

\section{Results}

Nine patients diagnosed with MCD were identified in our HIV/AIDS population. All patients were male and reported sex with men (MSM) as their risk for HIV infection. The mean age at MCD diagnosis was $39.22 \pm 11.40$; the mean CD4 cell count nadir was $68.33 \pm 62.2$ cells/ $\mathrm{mm}^{3} .85 \%(7 / 9)$ were on cART (combined antiretroviral therapy) at the time of MCD diagnosis with a mean CD4 count of $233.67 \pm 157.44$ cells $/ \mathrm{mm}^{3}$. MCD was of the hyaline vascular variant in 3 patients, plasma cell variant in 2 , transitional in 1 patient, and unspecified in 2 patients. Systemic symptoms were present in three patients. Five patients had both Kaposi sarcoma (KS) and MCD (2 with

\footnotetext{
* Correspondence: rnpilla@emory.edu

1 Winship Cancer Institute, Emory University, Atlanta, GA, USA

Full list of author information is available at the end of the article
}

KS occurring after MCD diagnosis, 1 with KS before MCD, 2 with KS and MCD diagnosed simultaneously). Most of the patients were anemic with mean hemoglobin of $8.99 \pm 4.04 \mathrm{~g} / \mathrm{dL}$ and hypoalbuminemic $(2.31 \pm 0.96) .85 \%$ had anemia, hepatosplenomegaly, and low albumin at diagnosis. Treatment consisted of valgancyclovir, chemotherapy and/or rituximab. In the 5 patients who died, the mean time from MCD diagnosis was $425.2 \pm 447$ days.

\section{Conclusions}

HIV-associated MCD is characterized by lymphadenopathy, splenomegaly, anemia and hypoalbuminemia. Among the diseases associated with HHV8 (KS, primary effusion lymphoma, and MCD), MCD appears to be the least affected by cART use or degree of immunosuppression [2]. In our cohort, $85 \%$ of patients had a CD4 count above 200 at MCD diagnosis. The survival with cART is still dismal, with one year survival of $50 \%$. Larger multicenter study is needed to better understand the pathogenesis of HIV-associated MCD and its treatment.

\footnotetext{
Author details

${ }^{1}$ Winship Cancer Institute, Emory University, Atlanta, GA, USA. ${ }^{2}$ Division of Infectious Diseases, Emory University School of Medicine, Atlanta, GA, USA. ${ }^{3}$ Infectious Disease Program, Grady Health System, Atlanta, GA, USA.

${ }^{4}$ Department of Pathology, Emory University School of Medicine, Atlanta, GA, USA.

Published: 19 April 2012

References

1. Powles T, Stebbing J, Bazeos A, et al: The role of immunosuppresssion and HHV-8 in the increasing incidence of HIV-associated multicentric Castleman's disease. Ann Oncol 2009, 20(4):775-9.

2. Myelona EE, Baraboutis IG, Lekakis LJ, et al: Multicentric Castleman's disease in HIV infection: a systematic review of the literature. AIDS ReV 2008, 10(1):25-35.
} 
doi:10.1186/1750-9378-7-S1-P20

Cite this article as: Pillai et al:: Multicentric Castleman's disease in HIV/

AIDS patients at an urban HIV clinic in Atlanta, Georgia, in the combined antiretroviral therapy era. Infectious Agents and Cancer 2012 7(Suppl 1):P20.

Submit your next manuscript to BioMed Central and take full advantage of:

- Convenient online submission

- Thorough peer review

- No space constraints or color figure charges

- Immediate publication on acceptance

- Inclusion in PubMed, CAS, Scopus and Google Scholar

- Research which is freely available for redistribution

Submit your manuscript at www.biomedcentral.com/submit

() BioMed Central 